\title{
A New Species of Boubou (Malaconotidae: Laniarius) from the Albertine Rift
}

\author{
Gary Voelker \\ Texas A \& M University - College Station \\ Robert K. Outlaw \\ University of Memphis \\ Sushma Reddy \\ Loyola University Chicago, sreddy6@luc.edu \\ Michael Tobler \\ Texas A \& M University - College Station \\ John M. Bates
}

See next page for additional authors

Follow this and additional works at: https://ecommons.luc.edu/biology_facpubs

Part of the Biology Commons

\section{Recommended Citation}

Voelker, G, RK Outlaw, S Reddy, M Tobler, JM Bates, SJ Hackett, C Kahindo, BD Marks, JC Kerbis Peterhans, and TP Gnoske. "A New Species of Boubou (Malaconotidae: Laniarius) from the Albertine Rift." The Auk 127(3), 2010.

This Article is brought to you for free and open access by the Faculty Publications and Other Works by Department at Loyola eCommons. It has been accepted for inclusion in Biology: Faculty Publications and Other Works by an authorized administrator of Loyola eCommons. For more information, please contact ecommons@luc.edu.

\section{(c) $(\mathrm{i})($ )}

This work is licensed under a Creative Commons Attribution-Noncommercial-No Derivative Works 3.0 License.

(c) The American Ornithologists' Union, 2010. 


\section{Authors}

Gary Voelker, Robert K. Outlaw, Sushma Reddy, Michael Tobler, John M. Bates, Shannon J. Hackett, Charles Kahindo, Ben D. Marks, Julian C. Kerbis Peterhans, and Thomas P. Gnoske 


\title{
A NEW SPECIES OF BOUBOU (MALACONOTIDAE: LANIARIUS) FROM THE ALBERTINE RIFT
}

\author{
Gary Voelker, ${ }^{1,7}$ Robert K. Outlaw, ${ }^{2}$ Sushma Reddy, ${ }^{3,4}$ Michael Tobler, ${ }^{1}$ \\ John M. Bates, ${ }^{4}$ Shannon J. Hackett, ${ }^{4}$ Charles Kahindo, ${ }^{5}$ Ben D. Marks, ${ }^{1}$ \\ Julian C. Kerbis Peterhans, ${ }^{4,6}$ and Thomas P. Gnoske ${ }^{4}$ \\ ${ }^{1}$ Department of Wildlife and Fisheries Sciences and Texas Cooperative Wildlife Collections, \\ Texas AEM University, College Station, Texas 77843, USA; \\ ${ }^{2}$ Department of Biology, University of Memphis, Memphis, Tennessee 38152, USA; \\ ${ }^{3}$ Department of Biology, Loyola University Chicago, Chicago, Illinois 60626, USA; \\ ${ }^{4}$ Department of Zoology, Field Museum of Natural History, Chicago, Illinois 60605, USA \\ ${ }^{5}$ Bukavu State University, P.O. Box 570, Bukavu, Democratic Republic of the Congo; and \\ ${ }^{6}$ College of Professional Studies, Roosevelt University, Chicago, Illinois 60605, USA
}

\begin{abstract}
We describe Laniarius willardi, a new species of boubou shrike (Malaconotidae) from the Albertine Rift of Africa. The most conspicuous, distinguishing morphological feature of the species is a gray to blue-gray iris. This and external morphometric data indicate that $L$. willardi is diagnosable from other black or sooty boubous. Further, $L$. willardi is genetically diagnosable, and its closest relative is the Mountain Sooty Boubou (L. poensis camerunensis) from Cameroon. The Crimson-breasted Bush-shrike (L. atrococcineus) and the Lowland Sooty Boubou (L. leucorhynchus) are together the sister clade to L. willardi-L.p. camerunensis. Laniarius willardi and the geographically codistributed $L . p$. holomelas differ by $11.5 \%$ in uncorrected sequence divergence, and elevational data taken from museum specimens suggest the possibility of elevational segregation of the species at $\sim 2,000 \mathrm{~m}$, with $L$. willardi occurring at lower elevations. Our broad sampling of black and sooty boubou taxa indicate that (1) races of Mountain Sooty Boubou (L. poensis) do not form a monophyletic clade; (2) L. p. camerunensis may represent multiple, nonsister lineages; and (3) at least one race of Fülleborn's Black Boubou (L.fuelleborni usambaricus) is genetically distinct from other races of that species. Received 16 June 2009, accepted 12 December 2009.
\end{abstract}

Key words: Africa, boubou, Laniarius, Malaconotidae, shrikes.

\section{Une nouvelle espèce de Laniarius (Malaconotidae) au Rift Albertine}

RÉSUMÉ.-Nous décrivons ici Laniarius willardi, une nouvelle espèce de la famille des Malaconotidae vivant au Rift Albertine, en Afrique. Le caractère morphologique le plus remarquable de cette espèce est un iris gris à bleu-gris. Ceci et des données morphométriques externes indiquent que L. willardi est différent des autres Laniarius. De plus, L. willardi est génétiquement différent et son plus proche parent est L. poensis camerunensis, au Cameroun. L. atrococcineus et L. leucorhynchus forment le clade sæur de L. willardiL.p. camerunensis. L. willardi et L. p. holomelas, dont la répartition géographique est similaire, diffèrent de $11,5 \%$ en ce qui concerne la divergence de la séquence corrigée. Les données altitudinales récoltées sur des spécimens de musée suggèrent qu'il existe une possibilité de ségrégation altitudinale des espèces à $\sim 2000 \mathrm{~m}, L$. willardi étant présent à des altitudes plus faibles. Notre vaste échantillonnage de ce taxon indique que (1) les races L. poensis ne forment pas un clade monophylétique, (2) L. p. camerunensis peut représenter des lignées multiples qui ne sont pas sæurs et (3) au moins une race de L. fuelleborni usambaricus est génétiquement distincte des autres races de cette espèce.

CLASSIFIED AS A biodiversity hotspot (Mittermeier et al. 2005), the Albertine Rift in East Africa contains more vertebrate species and more vertebrate endemic species than any other region in Africa (Plumptre et al. 2007). The high species richness of birds is attributable, in part, to the fact that a substantial number of taxa reach a distributional limit at the rift (Sinclair and Ryan 2003).
For example, three species of black or sooty boubou shrikes (Malaconotidae), the Lowland Sooty Boubou (Laniarius leucorhynchus), Mountain Sooty Boubou (L. poensis), and Slate-colored Boubou (L. funebris), have ranges that to some extent occur within or border the Albertine Rift. Yet another black Laniarius species, Fülleborne's Boubou (L.fuelleborni), occurs in the nearby Eastern

${ }^{7}$ E-mail: gvoelker@tamu.edu

The Auk, Vol.127, Number 3, pages 678-689. ISSN 0004-8038, electronic ISSN 1938-4254. @ 2010 by The American Ornithologists' Union. All rights reserved. Please direct all requests for permission to photocopy or reproduce article content through the University of California Press's Rights and Permissions website, http://www.ucpressjournals. com/reprintInfo.asp. DOI: 10.1525/auk.2010.09014 
Arc Mountains of Tanzania and Kenya, the western extent of the Eastern Afromontane hotspot and another region of high vertebrate endemism (Burgess et al. 2007).

In 1997, T.P.G., C.K., and B.D.M. conducted collections-based field work in the southern region of Uganda, in the Albertine Rift system. Their survey was conducted on privately held property primarily used as a banana plantation, which included the only forest contiguous with the Bwindi Impenetrable National Park in the area. During this survey, they collected 4 black Laniarius specimens that they were forced to attribute to L. poensis holomelas on the basis of size and plumage characteristics. However, these specimens, and an additional Field Museum of Natural History (FMNH) specimen collected in Burundi in 1991, were noted as having a unique iris color (gray to blue-gray) unlike that shown for any black Laniarius species in field guides (reddish-black to black). We could find no published reports describing blue-gray irides in adults of black Laniarius species, which reinforced concerns about the identification of these specimens (Marks et al. 2003).

Further questions related to species limits and taxonomy of black Laniarius species are raised by the broader distributions of $L$. poensis and L. fuelleborni. The former has a significant geographic disjunction between subspecies in the Albertine Rift and Mt. Cameroon (Fig. 1), and the latter has populations isolated on different mountains of the Eastern Arc, as well as a population in southwestern Tanzania and northern Malawi (Fry et al. 2000). Taxonomically, these two species have been linked; races of L. poensis were historically recognized as subspecies of L. fuelleborni (Mayr and Greenway 1960). Also, L. poensis and L. fuelleborni along with L. leucorhynchus are considered a superspecies (Fry et al. 2000). However, no phylogenetic study has addressed the relationships among these populations.
We had two goals in the present study. First, we conducted phylogenetic and morphometric analyses to determine whether the gray to blue-gray iris (hereafter "gray") color reported for 5 Laniarius specimens (Marks et al. 2003) represents an unreported geographic variant of a currently described black Laniarius species, or whether the unique iris color indicates a cryptic species new to science. Second, our sampling of black Laniarius species allowed us to present an overview of phylogenetic relationships and to propose preliminary taxonomic recommendations for the group.

\section{Methods}

\section{Morphology}

We sought to address two questions related to morphology. First, is the gray iris variant morphologically distinct from its sister taxon (see below), and second, does morphology distinguish the gray iris variant from other dark Laniarius species, particularly those that are sympatric with it? We took morphological measurements from 12 individuals of L. fuelleborni, 53 of L. poensis holomelas, a combined 9 individuals of L.p. poensis and L. p. camerunensis, 6 of $L$. leucorhynchus, and 4 of the gray iris variant (the fifth is a skeletal preparation). To the gray iris variant group, we added 9 individuals of L. p. holomelas from the American Museum of Natural History (AMNH) that, according to specimen labels, exhibited gray irides (no significant morphological differences were found between the two groups; multivariate analysis of covariance [MANCOVA] : $F=1.527, \mathrm{df}=4$ and $7, P=0.293$ ). Just 5 of the 85 specimens of $L . p$. holomelas housed at the Royal Museum for Central Africa had iris color recorded, and none was gray (G. Voelker pers. obs.); hence, we did not include those in our analyses.

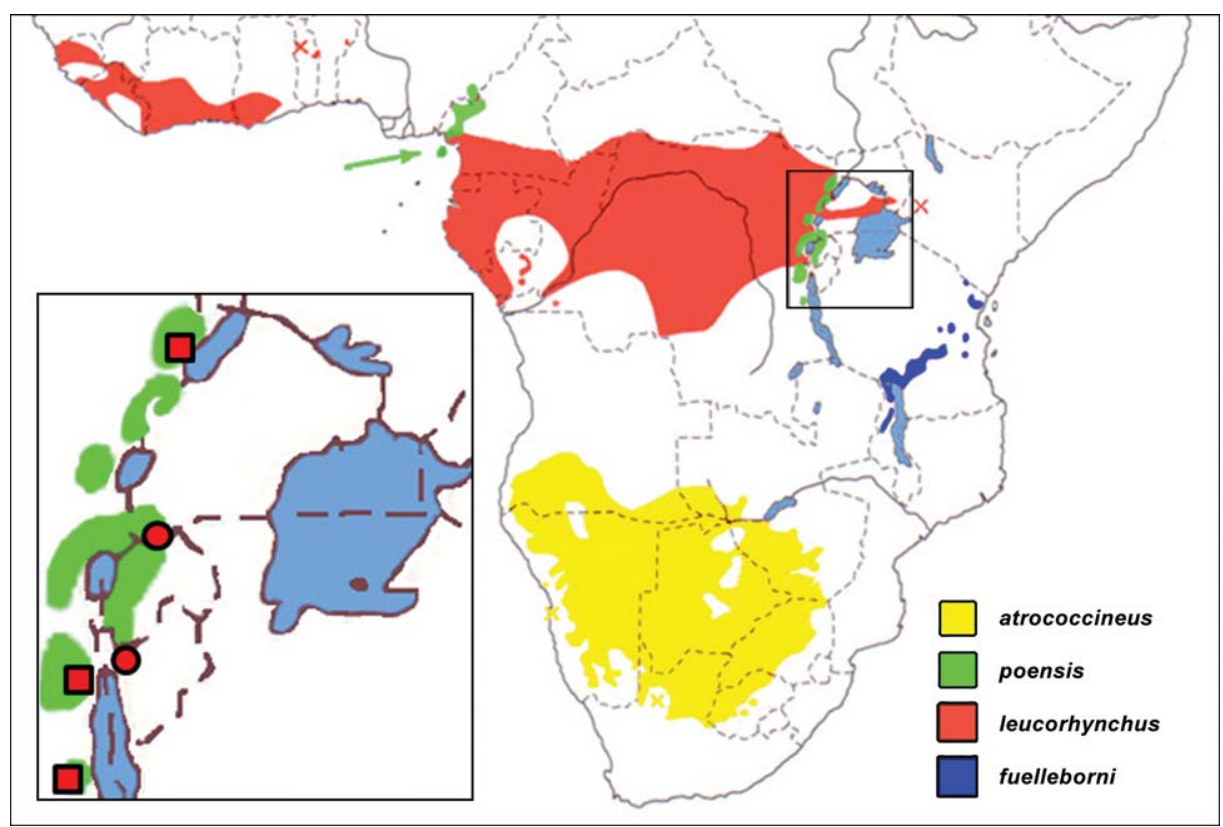

FIG. 1. Distributions of Laniarius atrococcineus, L. poensis, L. leucorhynchus, and L. fuelleborni. Light blue indicates lakes. Inset: distribution of L. willardi, overlaid on the distribution of $L$. poensis. Red circles indicate general collecting localities of the $L$. willardi type series; red squares indicate general collecting localities of specimens presumed to be $L$. willardi on the basis of iris color and morphology (see text). 
All specimens measured were adults, and sexes were combined for analyses. Measurements were taken with digital calipers (by G.V.) and rounded to the nearest $0.1 \mathrm{~mm}$. They included wing chord (WCH), tail length (from point of feather insertion to tip of central rectrix; TAIL), tarsus length (TS), exposed culmen length (CUL), and bill width at anterior edge of nares (BWID). Weights to the nearest $0.1 \mathrm{~g}$ were obtained in the field before preparation, using a Pesola spring scale. All measured specimens included herein are housed at the FMNH or the AMNH (Appendix).

Morphological data were analyzed using MANCOVA. Assumptions of multivariate normal error and homogeneity of variances and covariances were met for all analyses performed. $F$ ratios were approximated using Wilks's lambda and effect strengths using partial eta squared $\left(\eta_{\mathrm{p}}^{2}\right)$. To control for multivariate allometry, we used TS as a covariate in the model. Each individual was assigned to one of five groups (corresponding to putative species: L. fuelleborni, L. p. holomelas, L. p. poensis [combined with L. p camerunensis], L. leucorhynchus, and the gray iris variant), and "species" was included as the independent variable.

To provide another intuitive measure of effect strengths, we conducted a heuristic discriminant function analysis (DFA) to determine the percentage of specimens that could be correctly classified to the correct species on the basis of morphometric data. To do so, we first removed the effects of allometry by using residuals of a preparatory MANCOVA. In this MANCOVA, morphological traits were used as dependent variables and TS as a covariate.

\section{Molecular Methods and Sequence Alignment}

We sequenced mtDNA from a total of 54 individuals of black Laniarius species (Appendix), focusing primarily on L. p. camerunensis $(n=2), L$. $p$. holomelas $(n=25)$, L. fuelleborni $(n=15)$ and the five FMNH individuals of the gray iris variant. These included samples from Cameroon, the Democratic Republic of the Congo, Uganda, Burundi, Malawi, Zambia, and Tanzania. We also sequenced 6 individuals of L. leucorhynchus (Albertine Rift and west in lowland forest) and 1 of L. funebris (Albertine Rift and east in dry forest). Whole genomic DNA was extracted from tissue or museum specimen toepads using the DNeasy tissue extraction kit (Qiagen, Valencia, California). We used polymerase chain reaction (PCR) to amplify the mitochondrial NADH dehydrogenase subunit 2 (ND2) using newly developed primers (L185: GCYGCTACTAAGTACTTCCTAAC and H790: GTTAGTTCTTGGATAATGAGTCA) and previously published primers and protocols (Outlaw et al. 2007, 2010). Automated sequencing was performed with BigDye (Applied Biosystems, Foster City, California) and products were run out on an $\mathrm{ABI} 377$ or $\mathrm{ABI} 3100$ sequencer We used SEQUENCHER, version 4.7 (Gene Codes, Ann Arbor, Michigan), to align 700-1,041 base pairs (bp) of ND2 from each sample except FMNH 95873, from which we obtained only $300 \mathrm{bp}$ Sequences have been deposited in GenBank under accession numbers HM119437-HM119484.

\section{Phylogenetic Analyses}

We included previously published sequences from other Laniarius species (obtained from GenBank) in our phylogenetic analysis (Nguembock et al. 2008). These included additional black boubous (L. fuelleborni from Tanzania $[n=2]$, L. poensis $[n=2$; one each from Cameroon and Burundi], and L. funebris [ $n=2])$, and 12 additional bush-shrike species.

MODELTEST, version 3.04 (Posada and Crandall 1998), was used to select the most appropriate model of sequence evolution for our data. Hierarchical likelihood ratio tests and Akaike's information criterion identified $\mathrm{GTR}+\mathrm{I}+\Gamma$ as the best-fitting model. Using PAUP* (Swofford 2002), we performed a maximumlikelihood (ML) search using parameters estimated from a logdet neighbor-joining topology. This initial search ran for $>16,000$ rearrangements, with no changes in likelihood score after 5,000 rearrangements. We reestimated $\mathrm{GTR}+\mathrm{I}+\Gamma$ parameters and ran a second ML search to completion at $>230,000$ rearrangements. Relationships among major clades did not change between searches.

Support for relationships was assessed using MRBAYES, version 3.1.2 (Huelsenbeck and Ronquist 2001). Four Bayesian analyses were initiated from random starting trees, with four Markov-chain Monte Carlo chains run for 2 million generations and sampled every 100 generations, yielding 20,000 trees each. The first 5,000 trees from each analysis were discarded to help ensure chain stationarity. All remaining trees were combined, yielding a total of 60,000 topologies from which a $50 \%$ majorityrule consensus tree was reconstructed. Nodes with posterior probability values $\geq 0.95$ were deemed significantly supported. We further assessed node support using ML bootstrap analysis in TREEFINDER (Jobb 2008), using the GTR $+\mathrm{I}+\Gamma$ model with 2,000 pseudoreplicates.

\section{Results}

\author{
Laniarius willardi, sp. nov. Voelker \& Gnoske \\ Willard's Sooty Boubou \\ Gonolekfuligineux de Willard (French name)
}

Holotype.-FMNH 384980; adult male (skull 100\% pneumatized); from Nteko, Kisoro District, southern Uganda $\left(1^{\circ} 1^{\prime} 59^{\prime \prime} \mathrm{S}, 29^{\circ} 37^{\prime} \mathrm{E}\right)$, mixed hardwood forest habitat, elevation 1,600 m; collected 21 May 1997 by B.D.M. and prepared as a study skin. DNA sequence obtained from toe pads is deposited in GenBank (accession no. HM119437).

Diagnosis.-All aspects of plumage, bill, and legs black (2.5Y $2 / 0$, based on Munsell color standards) with only slight hint of plumage iridescence. Distinguished from all other black shrikes by iris color, which ranges from gray to blue-gray across the type series (Fig. 2 and Table 1). Visually identical to L. poensis in plumage color, and similar in average morphological measurements (Table 2; but see below). Distinguished morphologically from $L$. leucorhynchus by smaller overall size (Fig. 2 and Table 2) and from $L$. funebris by plumage color (black, vs. dark slate in L. funebris).

Description of holotype.-Plumage black (2.5Y 2/0, based on Munsell color standards). Soft parts in life: iris blue-gray, bill and legs black.

Measurements of holotype.-Wing chord $80.2 \mathrm{~mm}$, tail 74.2 $\mathrm{mm}$, tarsus $28.8 \mathrm{~mm}$, culmen from base of feathers $19.2 \mathrm{~mm}$, bill width at anterior edge of nares $6.0 \mathrm{~mm}$, body mass $44.7 \mathrm{~g}$, skull $100 \%$ pneumatized, left testis $2 \times 1 \mathrm{~mm}$.

Allotype.-FMNH 384981; adult female (skull 95\% pneumatized, ovary $7 \times 3 \mathrm{~mm}$ ); from Nteko, Kisoro District, southern Uganda $\left(1^{\circ} 1^{\prime} 59^{\prime \prime} \mathrm{S}, 29^{\circ} 37^{\prime} \mathrm{E}\right)$, mixed hardwood forest habitat, 


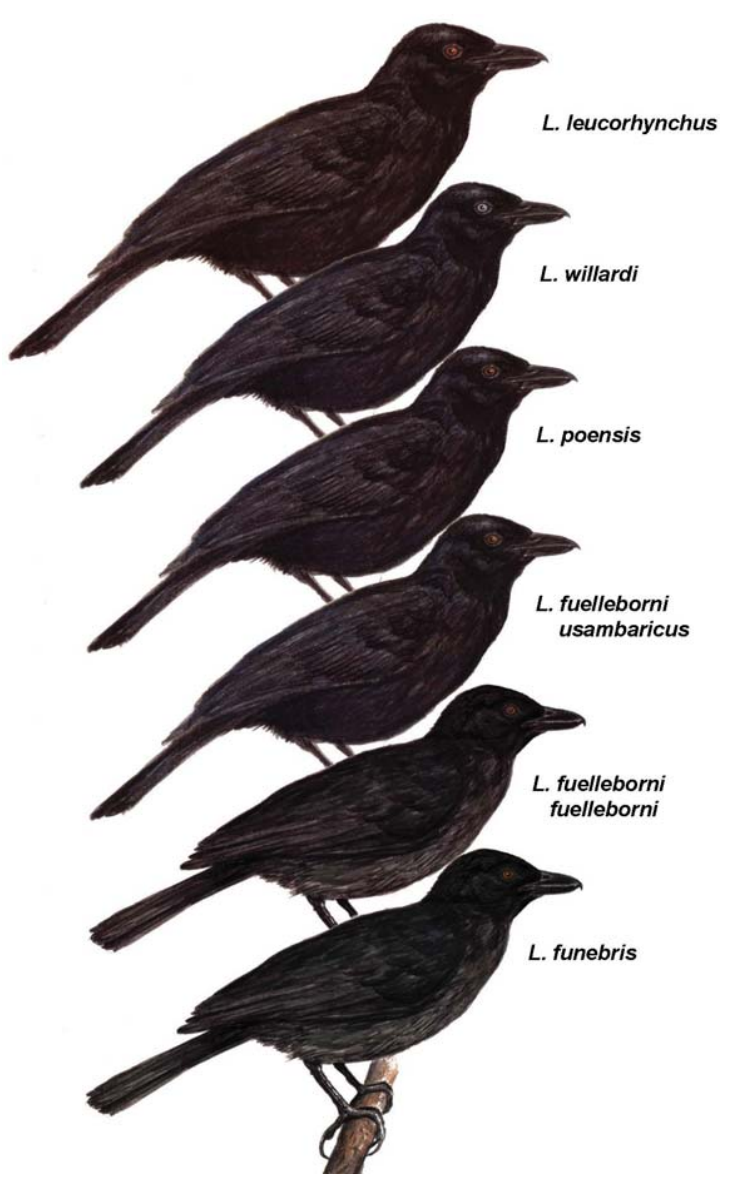

FIG. 2. Black and sooty boubou species of the genus Laniarius. elevation 1,600 m; collected 13 May 1997 by T.P.G. and prepared as a study skin, tissue preserved in buffer. DNA sequences are deposited in GenBank (accession no. HM119441).

Description and measurements of allotype.-Plumage black (2.5Y 2/0, based on Munsell color standards). Soft parts in life: iris blue-gray, bill and legs black. Wing chord $77.1 \mathrm{~mm}$, tail $71.4 \mathrm{~mm}$, tarsus $28.3 \mathrm{~mm}$, culmen from base of feathers $17.7 \mathrm{~mm}$, bill width at anterior edge of nares $6.3 \mathrm{~mm}$, body mass $40.5 \mathrm{~g}$, skull $95 \%$ pneumatized, ovary $7 \times 3 \mathrm{~mm}$.

Paratypes.-There are 3 additional specimens from the type series, all deposited at FMNH with associated tissue samples. Two specimens are from Nteko: FMNH 384982, male, study skin; and FMNH 384983, male, skeleton specimen. One specimen (FMNH $358003)$ is from Kibira National Park, Burundi $\left(2^{\circ} \mathrm{S}, 29^{\circ} 22^{\prime} 59^{\prime \prime} \mathrm{E}\right)$, male, study skin, collected 12 August 1991. Morphological measurements of the type series are given in Table 1.

Morphological separation of Laniarius willardi from similarly plumaged species in the genus.-Table 2 lists the descriptive statistics for each morphological trait in the four species. Morphologi$\mathrm{cal}$ analyses revealed significant allometric effects $(F=3.101, \mathrm{df}=$ 4 and $\left.71, P=0.021, \eta_{\mathrm{p}}^{2}=0.149\right)$ and a pronounced differentiation among species $\left(F=11.706, \mathrm{df}=16\right.$ and $\left.296, P<0.001, \eta_{\mathrm{p}}{ }^{2}=0.388\right)$. Post hoc comparisons (Fisher's LSD) revealed that L. willardi differs from its sister group $L . p$. camerunensis in $\mathrm{WCH}$ and TAIL ( $P \leq$ $0.002)$; from the sympatric $L . p$. holomelas in WCH, TAIL, and BWID $(P \leq 0.019)$; from $L$. fuelleborni in BWID $(P<0.001)$; and from $L$. leucorhynchus in all four morphological traits $(P \leq 0.048)$.

Using DFA, $>76.3 \%$ of the specimens (compared to the expected $20 \%$ under a null hypothesis of no pattern) could be assigned to the correct species solely on the basis of the four morphological measurements (Fig. 3 and Tables 3 and 4). Most importantly, the multivariate analyses and the DFA indicated that

TABLE 1. Morphological measurements and eye color of the type series of Laniarius willardi. Measurements are in millimeters, weight is in grams, and iris color was taken from specimen labels. Missing measurements are from a skeleton preparation.

\begin{tabular}{ccccccccc}
\hline FMNH & Sex & Weight & Wing & Tail & Tarsus & Culmen & Bill width & Iris color \\
\hline 358003 & M & 41.3 & 81.1 & 72.4 & 27.9 & 18.9 & 6.2 & Gray \\
384980 & M & 44.7 & 80.2 & 74.2 & 28.8 & 19.2 & 6.0 & Blue-gray \\
384981 & F & 40.5 & 77.1 & 71.4 & 28.3 & 17.7 & 6.3 & Blue-gray \\
384982 & M & 44.7 & 76.9 & 73.4 & 29.6 & 17.9 & 6.8 & Gray-blue \\
384983 & M & & & & & & & Gray \\
\hline
\end{tabular}

TABLE 2. Morphometric measurements of Laniarius willardi and other species used in multivariate comparisons (sexes combined; $\mathrm{WCH}=$ wing chord, TAIL = tail length, CUL = exposed culmen length, BWID = bill width at anterior edge of nares, and TS = tarsus length). Included in $L$. willardi are 9 American Museum of Natural History specimens with gray irides (see text). Laniarius poensis includes individuals of L. p. poensis and L. p. camerunensis.

\begin{tabular}{lrccccc}
\hline & \multicolumn{1}{c}{$n$} & WCH & TAIL & CUL & BWID & TS \\
\hline L. willardi & 13 & $73.9 \pm 3.2$ & $72.9 \pm 1.2$ & $18.4 \pm 0.7$ & $6.3 \pm 0.3$ & $28.6 \pm 0.9$ \\
L. poensis & 9 & $75.6 \pm 3.2$ & $64.3 \pm 2.5$ & $18.2 \pm 0.7$ & $6.1 \pm 0.4$ & $28.6 \pm 1.2$ \\
L.p. holomelas & 40 & $77.7 \pm 2.5$ & $70.3 \pm 2.3$ & $18.7 \pm 0.9$ & $6.1 \pm 0.4$ & $29.0 \pm 1.3$ \\
L. fuelleborni & 12 & $81.2 \pm 1.9$ & $75.9 \pm 3.8$ & $19.6 \pm 0.8$ & $5.6 \pm 0.3$ & $30.1 \pm 0.6$ \\
L. leucorhynchus & 6 & $90.2 \pm 2.9$ & $81.4 \pm 2.3$ & $22.9 \pm 0.9$ & $6.4 \pm 0.2$ & $29.6 \pm 1.7$ \\
\hline
\end{tabular}




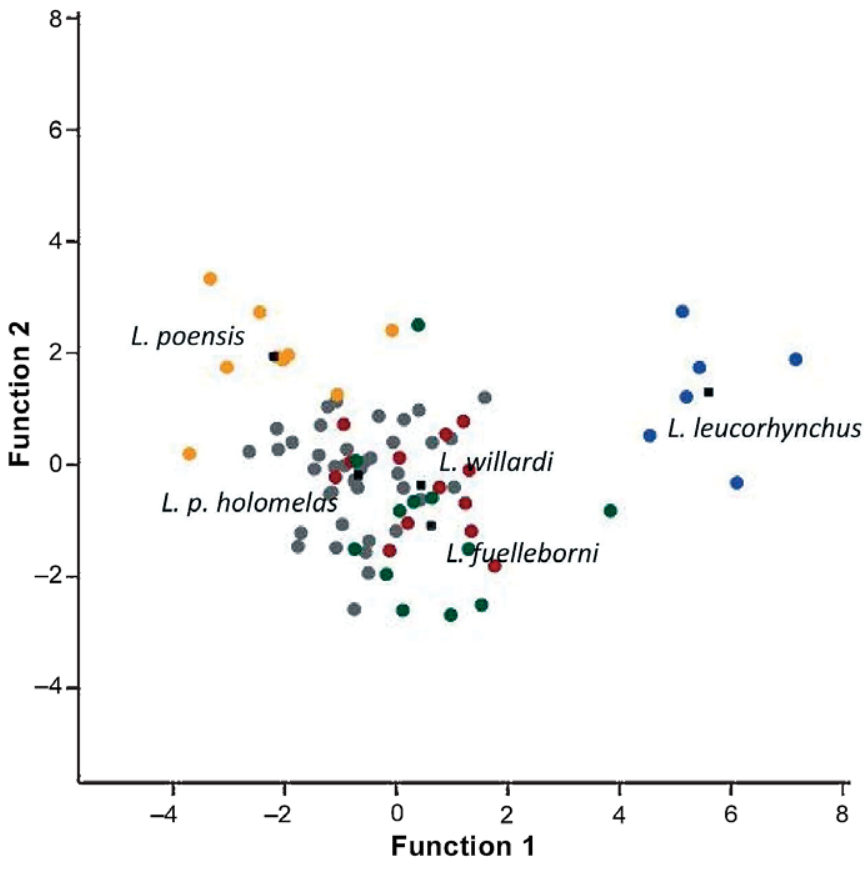

FIG. 3. Discriminant function plot of the first two discriminant functions based on morphological measurements. Squares represent group centroids; circles represent individuals of the respective species. Orange: Laniarius poensis; red: L. willardi; green: L. fuelleborni; gray: L. holomelas; blue: L. leucorhynchus. Included in L. willardi are $9 \mathrm{AMNH}$ individuals with gray irides (see text), and poensis includes individuals of $L$. p. poensis and L. p. camerunensis.

the morphology of $L$. willardi (including the 9 AMNH specimens recorded as having gray irides) is significantly different from its sister L. p. camerunensis (without any misclassifications between the two species; Table 4). There is morphological differentiation between the sympatric $L$. willardi and L. p. holomelas as indicated by the significant difference in WCH, TAIL, and BWID, but the DFA was not able to distinguish the two species in $100 \%$ of the cases (the classification success between the two species was
TABLE 3. Discriminant function analysis using morphological measurements of Laniarius willardi and other species (see Table 2; $\mathrm{WCH}=$ wing chord, $\mathrm{CUL}=$ exposed culmen length, BWID = bill width at anterior edge of nares, and TAIL = tail length). The table lists standardized canonical discriminant-function coefficients, canonical correlation, eigenvalue, percent variance explained, chi-square values, degrees of freedom, and the significance value for each of the six discriminant functions.

\begin{tabular}{lcccc}
\hline & Function 1 & Function 2 & Function 3 & Function 4 \\
\hline WCH & 0.301 & 0.495 & -0.379 & -1.031 \\
CUL & 0.606 & 0.250 & -0.424 & 0.646 \\
BWID & 0.081 & 0.628 & 0.736 & 0.187 \\
TAIL & 0.530 & -0.922 & 0.511 & 0.362 \\
& & & & \\
Canonical correlation & 0.880 & 0.671 & 0.495 & 0.129 \\
Eigenvalue & 3.422 & 0.819 & 0.325 & 0.017 \\
Percent variance & 74.7 & 17.9 & 7.1 & 0.4 \\
Chi-square & 177.55 & 66.80 & 22.22 & 1.25 \\
df & 16 & 9 & 4 & 1 \\
P & $<0.001$ & $<0.001$ & 0.001 & 0.263 \\
\hline
\end{tabular}

$90.1 \%$, compared with the expected $50 \%$ under a null hypothesis of no pattern).

Etymology.-The specific epithet honors our friend and colleague David Willard in recognition of his tireless, decades-long dedication to ornithological research, teaching, and conservation and to making the Bird Division of the FMNH one of the premier bird collections in the world. Innumerable ornithologists have been, and will be, beneficiaries of his efforts. The English common name of Willard's Sooty Boubou highlights the plumage of the species.

Distribution and elevation.-The type series indicates that the distributional range of $L$. willardi is limited to two Albertine Rift localities: Nteko, Kisoro District, Uganda $\left(1^{\circ} 1^{\prime} 59^{\prime \prime} \mathrm{S}, 29^{\circ} 37^{\prime} \mathrm{E}\right)$, and Kibira National Park, Burundi $\left(2^{\circ} \mathrm{S}, 29^{\circ} 22^{\prime} 59^{\prime \prime} \mathrm{E}\right)$. These localities are latitudinally separated by just a few hundred kilometers and are nearly identical in longitudinal coordinates. All Ugandan specimens were collected at 1,600 m, whereas the Burundian specimen was collected at $1,950 \mathrm{~m}$. These sites are along the lower eastern slopes of the Albertine Rift.

TABLE 4. Classification results of the discriminant function analysis across measured Laniarius taxa; included in L. willardi are 9 AMNH individuals with gray irides (see text), and L. poensis includes individuals of $L$. p. poensis and L. p. camerunensis. Overall, $76.3 \%$ of specimens (compared to the expected $20 \%$ under a null hypothesis of no pattern) were classified to the correct species on the basis of size-corrected morphological measurements. Correctly classified individuals and percentages are in bold.

\begin{tabular}{|c|c|c|c|c|c|c|}
\hline & & \multicolumn{5}{|c|}{ Predicted group membership } \\
\hline & & L.p. holomelas & L. willardi & L.p.poensis & L. leucorhynchus & L. fuelleborni \\
\hline \multirow[t]{5}{*}{ Original count } & L.p. holomelas & 28 & 3 & 3 & 0 & 6 \\
\hline & L. willardi & 1 & 11 & 0 & 0 & 1 \\
\hline & L.p.poensis & 1 & 0 & 8 & 0 & 0 \\
\hline & L. leucorhynchus & 0 & 0 & 0 & 6 & 0 \\
\hline & L. fuelleborni & 2 & 0 & 1 & 1 & 8 \\
\hline \multirow[t]{5}{*}{ Percent $(\%)$} & L.p. holomelas & 70.0 & 7.5 & 7.5 & 0.0 & 15.0 \\
\hline & L. willardi & 7.7 & 84.6 & 0.0 & 0.0 & 7.7 \\
\hline & L.p.poensis & 11.1 & 0.0 & 88.9 & 0.0 & 0.0 \\
\hline & L. leucorhynchus & 0.0 & 0.0 & 0.0 & 100.0 & 0.0 \\
\hline & L. fuelleborni & 16.7 & 0.0 & 8.3 & 8.3 & 66.7 \\
\hline
\end{tabular}




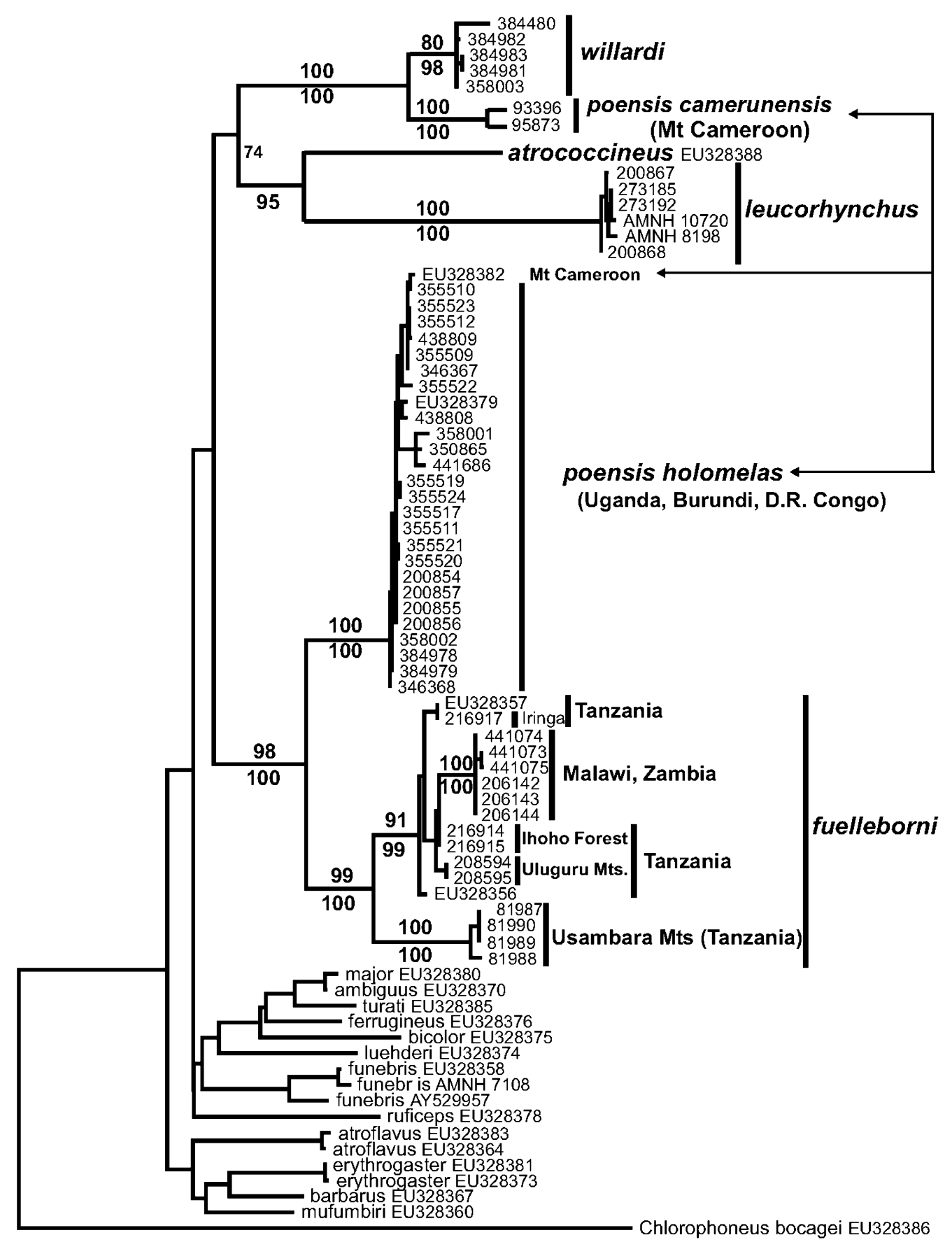

- 0.01 substitutions/site

FIG. 4. Maximum-likelihood phylogeny of bush-shrikes and boubous, based on ND2 data. Numbers above nodes are maximum-likelihood bootstrap support percentages, and numbers below nodes are Bayesian posterior probabilities. All sample numbers represent Field Museum of Natural History voucher specimens, except samples from the American Museum of Natural History (AMNH), or GenBank (prefaced by EU or AY).

\section{Phylogenetic Relationships}

Across 700-1039 bp of ND2, for all taxa including outgroup species, 352 bp were parsimony-informative. Within L. willardi, $L$. poensis, L. fuelleborni, L. atrococcineus, and L. leucorhynchus (see Fig. 4), 258 bp were parsimony-informative.
Phylogenetic results demonstrate that $L$. willardi is genetically distinct and diagnosable from all other black shrike taxa (Fig. 4). The closest relative of $L$. willardi is a clade consisting of two $L$. poensis collected on Mt. Cameroon (L. p. camerunensis; Fry et al. 2000), and the uncorrected percent sequence divergence between $L$. willardi and the L. p. camerunensis clade is 5\% (Fig. 4 and Table 5). 
TABLE 5. Uncorrected pairwise $(P)$ genetic distances between selected individuals from the willardi, poensis, and fuelleborni clades in the genus Laniarius.

\begin{tabular}{|c|c|c|c|c|c|c|c|}
\hline & 1 & 2 & 3 & 4 & 5 & 6 & 7 \\
\hline (1) L. willardi 384982 & - & & & & & & \\
\hline (2) L. poensis camerunensis 93396 (Mt. Cameroon) & 0.050 & - & & & & & \\
\hline (3) L. p. holomelas 355510 (Uganda) & 0.115 & 0.113 & - & & & & \\
\hline (4) L. fuelleborni 216917 (Iringa, Tanzania) & 0.103 & 0.119 & 0.077 & - & & & \\
\hline (5) L. fuelleborni 441074 (Malawi) & 0.126 & 0.120 & 0.090 & 0.030 & - & & \\
\hline (6) L. fuelleborni 216914 (Ihoho, Tanzania) & 0.105 & 0.114 & 0.081 & 0.014 & 0.018 & - & \\
\hline (7) L. fuelleborni 208595 (Ulugurus, Tanzania) & 0.101 & 0.110 & 0.080 & 0.016 & 0.024 & 0.007 & - \\
\hline (8) L. fuelleborni 81987 (Usambaras, Tanzania) & 0.120 & 0.126 & 0.087 & 0.066 & 0.061 & 0.059 & 0.063 \\
\hline
\end{tabular}

Sister to the L. willardi-L. p. camerunensis clade is a clade that consists of L. leucorhynchus and L. atrococcineus. Although bootstrap and posterior probabilities do not support this clade as sister to the L. willardi-L. p. camerunensis clade, genetic distances clearly indicate that other black shrikes are more distantly related to L. willardi and L. p. camerunensis (Table 5).

Finally, a large L. poensis clade is sister to L. fuelleborni. Phylogenetic results indicate virtually no genetic structure within L. poensis across its Albertine Rift distribution (L. p. holomelas) one individual from Mt. Cameroon (L. p. camerunensis) is not distinctly different from Albertine Rift individuals (Fig. 4). Conversely, phylogenetic results indicate geographic structure in $L$. fuelleborni, and in particular show that L.f. usambaricus (Usambara Mountains) is genetically distinct from other L. fuelleborni taxa (Fig. 4 and Table 5).

\section{Discussion}

Morphology.-Chapin (1954) suggested that L. p. camerunensis has a deeper, glossier black plumage than L. p. holomelas (Albertine Rift). We are unable to address this observation here because of the limited number of L. p. camerunensis in the FMNH and AMNH collections, but we find the plumage of $L$. willardi to be identical to the Albertine Rift endemic L. p. holomelas. Morphological analyses (Tables 2 and 4 and Fig. 3 ) indicate that L. willardi is distinguishable from its geographically disjunct sister L. p. camerunensis. Further, L. willardi is distinguishable from L. fuelleborni, which it does not geographically overlap, and more importantly it is generally distinguishable from the sympatric L. p. holomelas, although three L. p. holomelas were misclassified as L. willardi (Table 4). However, in just one instance was an L. willardi specimen misclassified as L. p. holomelas, and that specimen (AMNH 662381) was one of those pooled with willardi solely on the basis of recorded iris color. There is no skull ossification data for the specimen, but if it is a juvenile, iris color may indicate a juvenile $L$. $p$. holomelas (see below).

Iris color.-The gray to blue-gray irides reported for L. willardi are unique for an adult black Laniarius, and our morphological results indicate that the AMNH specimens with gray irides can generally be assigned to L. willardi. Given the age of these specimens (all collected in 1908), it is surprising that gray iris color has not been recorded in the literature. Bluish black eyes are described for L. p. camerunensis (Cameroon and Nigeria; Fry et al. 2000, Fry 2009). For L. p. holomelas, Harris (2000) described eye color as ranging from brown to blackish-brown throughout the range, and Chapin (1954) reported iris colors ranging from dark brown to deep red-brown for L. p. holomelas from the Congo. Of 85 L. $p$. holomelas in the Royal Museum for Central Africa, just 5 had iris color recorded (none gray). The FMNH series of L. p. holomelas collected from Uganda, Burundi, and the South Kivu region of the Democratic Republic of the Congo in the years 1990, 1991, 1997, and $2003(n=22)$ have iris colors recorded as either various shades of browns and reds or black. One specimen from Uganda (FMNH 355520; genetically L. p. holomelas; Fig. 4) had slate gray irises, but skull ossification (0\%) suggests that this individual is a juvenile.

Distribution and elevation.-If we accept that the AMNH specimens with gray irides (except AMNH 662381) are L. willardi, then the range of $L$. willardi includes (or historically included) the following locations in the Democratic Republic of the Congo: west of Lake Albert Edward (3 specimens); northwest of Lake Tanganyika, near Baraka (4 specimens); and west of Lake Tanganyika (1 specimen) (Fig. 1). These additional localities plus those from the type series suggest that $L$. willardi has a geographic distribution in the Albertine Rift similar to that mapped for L. p. holomelas (see Fry et al. 2000). Given the collecting localities of the type series (eastern side of the rift), it is probable that $L$. willardi will be found in Rwanda, particularly in the Nyungwe Forest. On the basis of 18 weeks in the field with 24 days of mist netting, DowsettLemaire (1990) recorded L. p. holomelas throughout the Nyungwe Forest and noted that it was widely distributed, "with no altitudinal limits, but less common below $1950 \mathrm{~m}$."

Indeed, elevation may be useful in distinguishing between $L$. willardi and L. p. holomelas in the field, where (presumed) L. p. holomelas is recorded from 1,170 to $3,385 \mathrm{~m}$ (Fry et al. 2000). The elevations at which the type series of $L$. willardi were collected is generally low (1,600 and 1,950 m), and the AMNH series of gray iris variants are similarly from low elevations $(1,600-2,000 \mathrm{~m})$. The elevational range for all recently collected FMNH L. p. holomelas is 2,075-3,000 m; the lowest elevation is in Kibira National Park, Burundi, just $150 \mathrm{~m}$ higher than the elevation at which the Burundi paratype was collected at effectively the same geographic locality. These elevational distributions suggest that $L$. willardi is found at lower elevations than L. p. holomelas. Because little forest exists below 2,000 $\mathrm{m}$ in the Albertine Rift today, L. willardi is probably uncommon.

It is possible that elevational segregration between $L$. willardi and L. p. holomelas is related to altitudinal segregation of forest communities; studies conducted in other African montane 
systems have shown clear avian community turnover related to altitude (e.g., Romdal and Rahbek 2009). Ecological studies of Bwindi Impenetrable National Park, Uganda (Butynski 1984, Howard 1991, Anonymous 2005), suggest that there are three presumed climax forest communities, each dominated by a single species of tree, with dominance being dependent on altitude. At lower elevations around $1,500 \mathrm{~m}$, Parinari exelsa is dominant; around 2,000 m, Newtonia buchananii predominates; and at around 2,200 m, Chrysophyllum gorungosanum predominates. The Ugandan specimens of $L$. willardi and the $3 \mathrm{AMNH}$ specimens from west of Lake Albert were collected at an altitude $(1,600 \mathrm{~m})$ that is consistent with a Parinari-dominated forest community. We also note that $L$. willardi can be separated by habitat from L. leucorhynchus, which occupies lowland forest, and from L. funebris, which occupies dry bush country (Fry et al. 2000, Harris 2000).

Harris (2000) noted that "poensis" was potentially threatened because of its isolated montane distribution, but it is clear from our study that more than one species is involved. Thus, L. willardi is also threatened because of extensive habitat loss at the lower elevations they inhabit in comparison to L. p. holomelas.

Breeding.-Gonad size of 1 male (testes: $4 \times 3.5 \mathrm{~mm}$ ) and 1 female (ovary: $7 \times 3 \mathrm{~mm}$, no brood patch data) collected on 15 and 13 May, respectively, from Nteko, Uganda, suggest that breeding efforts were just completed or about to begin. Data taken from the Burundi specimen (testes: $7 \times 5 \mathrm{~mm}$, light brood patch, 12 August) suggest either a prolonged breeding season or variable breeding periods across the distributional range. The known breeding period of L. p. holomelas in the Albertine Rift is highly variable: April to May (and possibly June to July) at Itombwe in the Democratic Republic of the Congo (Fry et al. 2000), December to February in Uganda (Mackworth-Praed and Grant 1955, Brown and Britton 1980), and October in Rwanda (Dowsett-Lemaire 1990).

Comments on black-shrike systematics and taxonomic recommendations.-Nguembock et al. (2008) demonstrated that traditional morphology-based species groups for the genus Laniarius were not supported by molecular data. Among other findings, our results (Fig. 4) agree with theirs in that black Laniarius do not form a monophyletic species group and that L. leucorhynchus is sister to L. atrococcineus; thus, L. leucorhynchus, L. poensis, and L. fuelleborni do not form a superspecies, as has been assumed (Fry et al. 2000).

A major result of Nguembock et al. (2008) was strong evidence that the unvouchered species L. liberatus was nearly identical to samples of L. aethiopicus erlangeri, a population that had been unsampled in a previous study (Smith et al. 1991). It is clear from our overall phylogenetic results (Fig. 4) and our description of $L$. willardi that there are additional issues with respect to sampling that indicate that cryptic species or races worthy of elevation to species rank are embedded in the taxonomic names $L$. poensis and L. fuelleborni. Our finding of a unique clade of "poensis" from Mt. Cameroon suggests that two species may coexist there. Given that we did not include samples of nominate $L$. p. poensis (Bioko) in our phylogenetic analysis and that we have few samples from Mt. Cameroon (L. p. camerunensis), any taxonomic recommendations are premature, but there are potential implications for taxonomy and conservation.
At the very least, it appears that instead of $L$. poensis being the umbrella under which the Albertine Rift race L. holomelas falls, the latter should be recognized as a distinct species that includes at least some Mt. Cameroon individuals. In that vein, we note that the two L. p. camerunensis that form the sister clade of L. willardi were collected at fairly low altitudes of $1,220 \mathrm{~m}$ and $1,524 \mathrm{~m}$. Stuart (1986) reported that black shrikes in this genus did not occur at the highest elevations of the mountain but that they reached 2,300 $\mathrm{m}$. Of greater interest is that he cites records from the 1960s at much lower elevations ( $430 \mathrm{~m}$ and $600 \mathrm{~m}$ ). Stuart considered all West African black shrikes conspecific with fuelleborni and attributed the lower-elevation records to seasonal altitudinal migration. Elevation data are not recorded for the Mt. Cameroon individual (E. Pasquet pers. comm.) that was nested within the Albertine Rift clade of L. poensis in our phylogenetic analysis (GenBank sequence), but the phylogenetic results support a hypothesis that it could represent an unrelated higher-elevation population. If this were the case, it would reflect the same type of elevational segregation that we posit between L. willardi and L. p. holomelas in the Albertine Rift, which suggests that Mt. Cameroon individuals from high elevations could be part of the latter. On the basis of our data, the higher-elevation lineages show essentially no divergence between Mount Cameroon and the Albertine Rift.

Another unsampled population in the Nguembock et al. (2008) data set was L. fuelleborni usambaricus. There is a strong geographic and genetic break between L. fuelleborni from the Usambara Mountains of Tanzania and other L. fuelleborni taxa (Fig. 4 and Table 4; Fry et al. 2000). There is additional, less divergent structure in populations of $L$. fuelleborni from the rest of Tanzania and Malawi-Zambia. Additional study of L. fuelleborni is warranted to tease apart genetic, morphological, and other data that could support the recognition of species rank for L. f. usambaricus or other races.

Why was Laniarius willardi overlooked?-Despite area species lists, fairly extensive work in the Albertine Rift (e.g., Chapin 1954, Prigogine 1980, Dowsett-Lemaire 1990, Dowsett-Lemaire and Dowsett 1990, Kalina and Butynski 1992), and specimens labeled with gray irides, $L$. willardi went undiscovered until our recent field work, when voucher material and modern specimenlabel data allowed for both genetic analysis and morphological confirmation of a distinct species. This is true despite the fact that L. willardi has a distinct blue-gray iris color that should have made it recognizable under thorough visual inspection. Perhaps habitat is a mitigating factor, in that eye color may not be particularly clear in low-light tropical forest settings. Ultimately, though, this bird was missed because of a lack of biodiversity research outside the scope of sight-survey-based studies and a lack of attention to museum specimen labels.

We believe that our general knowledge of avian biodiversity in Africa is less robust than it could be for a few reasons. First, there is a pervasive misconception that science knows most everything there is to know about that diversity. We reach this conclusion for several reasons, the most relevant of which is the increasing difficulty in obtaining scientific collecting permits for birds, the issuance of which are in our experience often hindered by nonscientific arguments of "overcollecting" (levied by permit authorities, or by people in a position to influence those authorities), or the existence of a sight-survey for a particular 
region (irrespective of the rigor of that survey). Interestingly, the "overcollecting" argument is, in our experience, rarely applied to nonbird taxa. A second underlying issue is that scientific collecting is often perceived as an anachronistic method with which to document and record avian biodiversity and to inform conservation decisions.

However, it is our contention that scientific collecting still has an imperative role in efforts to document and understand avian biodiversity in Africa (and other understudied areas) and to identify and preserve distinct lineages. We have previously called for collection of voucher specimens in support of this contention (Bates et al. 2004; see also Peterson et al. 2008). In Africa alone, several new species have been described in the past decade, all based on birds collected and prepared as research specimens (e.g., Beresford and Cracraft 1999, Liversidge and Voelker 2002, Beresford et al. 2004, Fjeldså et al. 2006, Schmidt et al. 2008, Bowie et al. 2009, present study). Still other studies have documented strong genetic differences between presumptive subspecies and, on this basis, elevated subspecies to specific rank (e.g., Bowie et al. 2003, 2005; present study). These results clearly should have an impact on conservation strategies.

These studies, our own ongoing work and that of others, and the vast areas of Africa that have never been scientifically sampled (or sampled during the "DNA age") suggest that there are likely numerous undescribed African species and populations of currently described species worthy of species rank. Only genetic and morphological analyses based on properly vouchered and appropriate series of specimens can provide significant documentation of these differences and, thus, expand our knowledge of avian biodiversity and inform conservation priorities.

\section{ACKNOWLEDGMENTS}

We thank V. Simeonovski for the shrike painting and S. Bober for the map. We thank the curators and collections managers at the American Museum of Natural History and the Royal Museum for Central Africa for access to specimens. We thank the governments of Burundi, the Democratic Republic of the Congo, and Uganda for permission to collect and export specimens. L. Davenport was responsible for all logistical details and field support in Burundi supported by the U.S. Peace Corps-USAID Biological Diversity Project (P. Trenchard, former director). For permission to work in Kibira National Park, Burundi, we gratefully acknowledge the Institut National pour l'Environment et la Conservacion de la Nature (A Nyokindi and L. Ntahuga, Directeurs General). We are indebted to P. K. Austin, A. J. Fisher, and A. Nibizi for their field collaboration with J.C.K.P. in Burundi, which provided essential comparative material. Financial support from the Ellen Thorne Smith, Conover, and Marshall Field III Funds of the Field Museum of Natural History (FMNH) partially covered field expenses in Burundi. The work of J.C.K.P. in Chicago was partially supported by the W. and J. Street Fund and, while he was a postdoctoral associate of the Center for Evolutionary and Environmental Biology, by FMNH. M.T. was supported by the Swiss National Science Foundation. Ugandan specimens from Bwindi Impenetrable National Park (BINP) were collected under the auspices of a John D. and Catherine T. MacArthur Foundation award (J.C.K.P., principal investigator). We thank S. Cavell, former director of the Bwindi Trust, K. Musana, and the Institute for Tropical Forest Conservation for critical assistance and coordination in BINP. Participants in the African Tropical Biodiversity Program collected some of the BINP specimens under consideration here. S. Jennings and M. Gray provided critical assistance and logistical support during the Ugandan surveys and training programs at BINP. Specimens from the Democratic Republic of the Congo were gathered under the auspices of a second MacArthur Foundation award to J.M.B. (FMNH, J.C.K.P., co-principal investigator), for which we acknowledge R. Kizungu and J. Mwanga. We thank R. Kityo, Curator, Makerere Museum of Zoology; D. Pomeroy of the Makerere University Institute of Environment and Natural Resources (MUIENR); and P Kasoma, former director of MUIENR, for far-reaching support without which these results would not have been possible. The genetic data for the project were gathered in G.V.'s lab and at the Pritzker Laboratory for Molecular Systematics and Evolution at FMNH. Sequencing costs were covered by FMNH and by National Science Foundation grant DEB-0613668 to G.V. and R. C. K. Bowie. This is publication number 1215 of the Texas Cooperative Wildlife Collection and number 176 of the Center for Biosystematics and Biodiversity, both at Texas A\&M University.

\section{Literature Cited}

Anonymous. 2005. Bwindi Impenetrable National Park, Uganda United Nations Environment Programme.

Bates, J. M., R. C. K. Bowie, D. E. Willard, G. Voelker, and C. KAHINDO. 2004. A need for continued collecting of avian voucher specimens in Africa: Why blood is not enough. Ostrich 75:187-191.

Beresford, P., AND J. CRACRAFT. 1999. Speciation in African forest robins (Stiphrornis): Species limits, phylogenetic relationships, and molecular biogeography. American Museum Novitates, no. 3270.

Beresford, P., J. FJELDSÅ, AND J. KiURE. 2004. A new species of Akalat (Sheppardia) narrowly endemic in the Eastern Arc of Tanzania. Auk 121:23-34.

Bowie, R. C. K., P. Bloomer, P. A. Clancey, and T. M. Crowe. 2003. The Karoo Thrush (Turdus smithi Bonaparte 1850), a southern African endemic. Ostrich 74:1-7.

Bowie, R. C. K., J. FJeldsÅ, AND J. KiURE. 2009. Multilocus molecular DNA variation in Winifred's Warbler Scepomycter winifredae suggests cryptic speciation and the existence of a threatened species in the Rubeho-Ukaguru Mountains of Tanzania. Ibis 151:709-719.

Bowie, R. C. K., G. VoelKer, J. FJeLsDÅ, L. Lens, S. J. Hackett, AND T. M. Crowe. 2005. Systematics of the Olive Thrush Turdus olivaceus species complex with reference to the taxonomic status of the endangered Taita Thrush T. helleri. Journal of Avian Biology 36:391-404.

BROWN, L. H., AND P. L. BRITTON. 1980. The breeding seasons of East African birds. East African Natural History Society, Nairobi, Kenya.

Burgess, N. D., T. M. Butynski, N. J. Cordeiro, N. H. Doggart, J. Fjelds Å, K. M. Howell, F. B. Kilahama, S. P. Loader, J. C. LOVETt, B. MBILINYI, AND OTHERs. 2007. The biological importance of the Eastern Arc Mountains of Tanzania and Kenya. Biological Conservation 134:209-231. 
ButYNSKI, T. 1984. Ecological survey of the Impenetrable (Bwindi) Forest, Uganda, and Recommendations for its Conservation and Management. New York Zoological Society, New York.

Chapin, J. B. 1954. The Birds of the Belgian Congo, Part 4. Bulletin of the American Museum of Natural History, vol. 75B.

Dowsett-Lemaire, F. 1990. Eco-ethology, distribution and status of Nyungwe Forest birds (Rwanda). Tauraco Research Reports 3:31-86.

Dowsett-Lemaire, F., And R. J. Dowsett. 1990. Zoogeography and taxonomic relationships of the forest birds of the Albertine Rift Afromontane region. Tauraco Research Reports 3:87-109.

FjeldsÅ, J., R. C. K. Bowie, And J. Kiure. 2006. The Forest Batis, Batis mixta, is two species: Description of a new, narrowly distributed Batis species in the Eastern Arc biodiversity hotspot. Journal of Ornithology 147:578-590.

FrY, C. H. 2009. Family Malaconotidae (Bush-shrikes). Pages 50-122 in Handbook of Birds of the World, vol. 14: Bush-shrikes to Old World Sparrows (J. del Hoyo, A. Elliott, and D. A Christie, Eds.). Lynx Edicions, Barcelona, Spain.

Fry, C. H., S. Keith, And E. K. Urban, Eds. 2000. The Birds of Africa, vol. 6. Academic Press, London.

HARris, T. 2000. Shrikes and Bush-shrikes. Princeton University Press, Princeton, New Jersey.

HowARD, P. 1991. Nature Conservation in Uganda's Tropical Forest Reserves. IUCN Conservation Library, Gland, Switzerland.

HuelsenbeCK, J. P., AND F. RonQuist. 2001. MRBAYES: Bayesian inference of phylogenetic trees. Bioinformatics 17:754-755.

JoBb, G. 2008. TREEFINDER. Distributed by the author. Munich, Germany. [Online.] Available at www.treefinder.org.

KAlinA, J., AND T. M. ButynsKi. 1992. Bird List: Impenetrable (Bwindi) Forest National Park. USAID, Uganda.

Liversidge, R., And G. Voelker. 2002. The Kimberley Pipit: A new African species. Bulletin of the British Ornithologists' Club 122:93-109.

Mackworth-Praed, C. W., and C. H. B. Grant. 1955. Birds of Eastern and North Eastern Africa, vol. 2. Longmans, London.

Marks, B. D., T. P. GNoske, And C. K. M. NgABO. 2003. Additions to the avifauna of Bwindi Impenetrable Forest and Echuya Forest Reserve, Uganda. Scopus 23:1-6.

Mayr, E., AND J. C. GreEnway, JR., Eds. 1960. Check-list of Birds of the World: A Continuation of the Work of James L. Peters, vol. 9 Museum of Comparative Zoology, Cambridge, Massachusetts.

Mittermeier, R. A., P. R. Gil, M. Hoffman, J. Pilgrim, T. Brooks, C. G. Mittermeier, J. Lamoreux, and G. A. B. DA FonsECA. 2005. Hotspots Revisited: Earth's Biologically Richest and Most Endangered Terrestrial Ecoregions. Conservation International, Arlington, Virginia.
Nguembock, B., J. Fjelds Å, A. Couloux, and E. Pasquet. 2008. Phylogeny of Laniarius: Molecular data reveal L. liberatus synonymous with L. erlangeri and "plumage coloration" as unreliable morphological characters for defining species and species groups. Molecular Phylogenetics and Evolution 48:396-407.

Outlaw, R. K., G. Voelker, And R. C. K. Bowie. 2010. Shall we chat? Evolutionary relationships in the genus Cercomela (Muscicapidae) and its relation to Oenanthe reveals extensive polyphyly among chats distributed in Africa, India and the Palearctic. Molecular Phylogenetics and Evolution 55:284-292.

Outlaw, R. K., G. Voelker, and D. C. Outlaw. 2007. Molecular systematics and historical biogeography of the rock-thrushes (Muscicapidae: Monticola). Auk 124:561-577.

Peterson, A. T., R. T. Brumfield, R. G. Moyle, Á. S. Nyári, J. V. Remsen, JR., AND M. B. RobBins. 2008. The need for proper vouchering in phylogenetic studies of birds. Molecular Phylogenetics and Evolution 45:1042-1044.

Plumptre, A. J., T. R. B. Davenport, M. Behangana, R. Kityo, G. Eilu, P. Ssegawa, C. Ewango, D. Meirte, C. Kahindo, M. Herremans, and others. 2007. The biodiversity of the Albertine Rift. Biological Conservation 134:178-194.

Posada, D., And K. A. CRAndall. 1998. MODELTEST: Testing the model of DNA substitution. Bioinformatics 14:817-818.

Prigogine, A. 1980. The altitudinal distribution of the avifauna in the Itombwe Forest (Zaire). Pages 169-184 in Proceedings of the Fourth Pan-African Ornithological Congress (D. N. Johnson, Ed.). South African Ornithological Society, Johannesburg.

ROMDAL, T. S., AND C. RAHBEK. 2009. Elevational zonation of Afrotropical forest bird communities along a homogeneous forest gradient. Journal of Biogeography 36:327-336.

Schmidt, B. K., J. T. Foster, G. R. Angehr, K. L. Durrant, And R. C. Fleischer. 2008. A new species of African forest robin from Gabon (Passeriformes: Muscicapidae: Stiphrornis). Zootaxa 1850:27-42.

SinClaIR, I., AND P. RYAN. 2003. Birds of Africa South of the Sahara. Struik, Cape Town, South Africa.

Smith, E. F. C., P. Arctander, J. Fjelds Å, And O. G. Amir. 1991. A news species of shrike (Laniidae: Laniarius) from Somalia, verified by DNA sequence data from the only known individual. Ibis 133:227-235

Stuart, S. N., Ed. 1986. Conservation of Cameroon Montane Forests. International Council for Bird Preservation, Cambridge, United Kingdom.

Swofford, D. L. 2002. PAUP*: Phylogenetic Analysis Using Parsimony (" and Other Methods), version 4.0b10. Sinauer Associates, Sunderland, Massachusetts.

Associate Editor: J. Klicka 
APPENDIX. General collection locality data for Laniarius samples used for phylogenetic and morphometric analyses.

\begin{tabular}{|c|c|c|}
\hline Species & Specimen number ${ }^{a, b, c}$ & Collection locality \\
\hline \multirow[t]{5}{*}{ L. willardi } & FMNH 358003 & Burundi: Cibitoke, Bukinanyama, Giserama, Kibira National Park \\
\hline & FMNH 384980 & Uganda: Southern, Kisoro, Nteko \\
\hline & FMNH 384981 & Uganda: Southern, Kisoro, Nteko \\
\hline & FMNH 384982 & Uganda: Southern, Kisoro, Nteko \\
\hline & FMNH $384983^{*}$ & Uganda: Southern, Kisoro, Nteko \\
\hline \multirow[t]{8}{*}{ L. poensis poensis } & AMNH $662374^{+}$ & Fernando Po \\
\hline & AMNH $662375^{+}$ & Fernando Po \\
\hline & AMNH $662376^{+}$ & Fernando Po \\
\hline & AMNH $662377^{+}$ & Fernando Po \\
\hline & AMNH $775704^{+}$ & Fernando Po \\
\hline & AMNH $781773^{+}$ & Fernando Po \\
\hline & AMNH $809729^{+}$ & Fernando Po \\
\hline & AMNH $809730^{+}$ & Fernando Po \\
\hline \multirow[t]{2}{*}{ L. p. camerunensis } & FMNH 93396* & Cameroon \\
\hline & FMNH $95874^{+}$ & Cameroon \\
\hline \multirow[t]{45}{*}{ L. p. holomelas } & FMNH 346367 & Burundi: Muramuya, Kibira National Park \\
\hline & FMNH 346368* & Burundi: Muramuya, Kibira National Park \\
\hline & FMNH 350865 & Burundi: Kayanza Prov., Kivuso Abri, Kibira National Park \\
\hline & FMNH 358001 & Burundi: Cibitoke, Bukinanyama, Giserama, Kibira National Park \\
\hline & FMNH 358002 & Burundi: Cibitoke, Bukinanyama, Giserama, Kibira National Park \\
\hline & FMNH 438808 & DRC: South Kivu, Tshivanga \\
\hline & FMNH 438809 & DRC: South Kivu, Tshivanga \\
\hline & FMNH 441686 & DRC: South Kivu, Tchibati, Kahuzi-Biega Nat Park \\
\hline & FMNH 384978 & Uganda: Southern, Kabale, Echuya Forest Reserve \\
\hline & FMNH 384979* & Uganda: Southern, Kabale, Echuya Forest Reserve \\
\hline & FMNH 200854 & Uganda: Western, Bwamba Valley, W slope Rwenzori \\
\hline & FMNH 200855 & Uganda: Western, Kalegalega, W slope Rwenzori \\
\hline & FMNH 200856 & Uganda: Western, Kazimbwa, W side Rwenzori \\
\hline & FMNH 200857 & Uganda: Western, Kalegalega, W slope Rwenzori \\
\hline & FMNH 355509 & Uganda: Western, Mahoma, Mubuku Valley, Rwenzori Mts. \\
\hline & FMNH 355510 & Uganda: Western, Mahoma, Mubuku Valley, Rwenzori Mts. \\
\hline & FMNH 355511 & Uganda: Western, Mahoma, Mubuku Valley, Rwenzori Mts. \\
\hline & FMNH 355512 & Uganda: Western, Mahoma, Mubuku Valley, Rwenzori Mts. \\
\hline & FMNH $355513^{+}$ & Uganda: Western, Mahoma, Mubuku Valley, Rwenzori Mts. \\
\hline & FMNH $355515^{+}$ & Uganda: Western, Mahoma, Mubuku Valley, Rwenzori Mts. \\
\hline & FMNH 355517 & Uganda: Western, Mahoma, Mubuku Valley, Rwenzori Mts. \\
\hline & FMNH 355519 & Uganda: Western, Nyabitaba, Mubuku Valley, Rwenzori Mts. \\
\hline & FMNH 355520 & Uganda: Western, Nyabitaba, Mubuku Valley, Rwenzori Mts. \\
\hline & FMNH 355521 & Uganda: Western, Nyabitaba, Mubuku Valley, Rwenzori Mts. \\
\hline & FMNH 355522 & Uganda: Western, Nyabitaba, Mubuku Valley, Rwenzori Mts. \\
\hline & FMNH 355523 & Uganda: Western, Nyabitaba, Mubuku Valley, Rwenzori Mts. \\
\hline & FMNH 355524 & Uganda: Western, Nyabitaba, Mubuku Valley, Rwenzori Mts. \\
\hline & FMNH $355526^{+}$ & Uganda: Western, Nyabitaba, Mubuku Valley, Rwenzori Mts. \\
\hline & AMNH $662378^{\dagger}$ & DRC: W of Tanganyika \\
\hline & AMNH $662379^{+}$ & DRC: W of Tanganyika \\
\hline & AMNH $662380^{\dagger}$ & DRC: W of Tanganyika \\
\hline & AMNH $662381^{\dagger}$ & DRC: W of Tanganyika \\
\hline & AMNH $662382^{+}$ & DRC: W of Tanganyika \\
\hline & AMNH $662383^{+}$ & None listed \\
\hline & AMNH $662384^{+}$ & DRC: W of Tanganyika \\
\hline & AMNH $662385^{\dagger}$ & Congo: N.W. Tanganyika, ca. Baraka \\
\hline & AMNH $662386^{+}$ & Congo: N.W. Tanganyika, ca. Baraka \\
\hline & AMNH $662387^{\dagger}$ & Congo: N.W. Tanganyika, ca. Baraka \\
\hline & AMNH $662388^{+}$ & Congo: N.W. Tanganyika, ca. Baraka \\
\hline & AMNH $662389^{+}$ & Rwanda: Rugege Forest \\
\hline & AMNH $662390^{+}$ & Rwanda: Rugege Forest \\
\hline & AMNH $662391^{\dagger}$ & Rugege Forest \\
\hline & AMNH $662392^{+}$ & Rwanda: Rugege Forest \\
\hline & AMNH $662393^{+}$ & Rwanda: Rugege Forest \\
\hline & AMNH $662394^{+}$ & Rwanda: Rugege Forest \\
\hline
\end{tabular}


Appendix. Continued.

\begin{tabular}{|c|c|c|}
\hline Species & Specimen number ${ }^{a, b, c}$ & Collection locality \\
\hline & AMNH $662395^{+}$ & Lake Kivu region \\
\hline & AMNH $662396^{+}$ & Kagera Kivu \\
\hline & AMNH $662397^{\dagger}$ & Kagera Kivu \\
\hline & AMNH $662398^{\dagger}$ & Kagera Kivu \\
\hline & AMNH $662399^{+}$ & Kagera Kivu \\
\hline & AMNH $662400^{+}$ & Kagera Kivu \\
\hline & AMNH $662401^{\dagger}$ & Kagera Kivu \\
\hline & AMNH $662402^{+}$ & Kagera Kivu \\
\hline & AMNH $662403^{+}$ & Kagera Kivu \\
\hline & AMNH $662405^{+}$ & Congo: West of Lake Albert Edward \\
\hline & AMNH $662406^{+}$ & West of Lake Albert Edward \\
\hline & AMNH $662407^{\dagger}$ & DRC: West of Lake Albert Edward \\
\hline & AMNH $662408^{+}$ & Ruwenzori \\
\hline & AMNH $662409^{+}$ & Uganda: Zuanda \\
\hline & AMNH $764834^{+}$ & Congo: NW of Lake Kivu, Bunyole \\
\hline & AMNH $764835^{+}$ & Congo: NW of Lake Kivu, Bunyole \\
\hline \multirow[t]{9}{*}{ L. fuelleborni } & FMNH 441073 & Malawi: Rumphi, Chilinda Camp, Nyika National Park \\
\hline & FMNH 441074 & Malawi: Rumphi, North Rukuru River \\
\hline & FMNH 441075 & Malawi: Rumphi, Chilinda Camp, Nyika National Park \\
\hline & FMNH 216914 & Tanzania: Ihoho Forest, Poroto Mts. \\
\hline & FMNH 216915 & Tanzania: Ihoho Forest, Poroto Mts. \\
\hline & FMNH 216917 & Tanzania: Dabaga Highlands \\
\hline & FMNH 206142 & Zambia: Lundazi, Chiri River headwaters \\
\hline & FMNH 206143 & Zambia: Lundazi, Chiri River headwaters \\
\hline & FMNH 206144 & Zambia: Lundazi, Chiri River headwaters \\
\hline \multirow[t]{4}{*}{ L.f. usambaricus } & FMNH $81987^{*}$ & Tanzania, Magamba, Usambara Mts. \\
\hline & FMNH 81988 & Tanzania, Magamba, Usambara Mts. \\
\hline & FMNH 81989 & Tanzania, Magamba, Usambara Mts. \\
\hline & FMNH 81990 & Tanzania, Magamba, Usambara Mts. \\
\hline \multirow[t]{2}{*}{ L.f. ulugurensis } & FMNH 208594 & Tanzania, Bunduki, Uluguru Mts. \\
\hline & FMNH 208595 & Tanzania, Bunduki, Uluguru Mts. \\
\hline \multirow[t]{11}{*}{ L. leucorhynchus } & AMNH DOT 8198* & Central African Republic \\
\hline & AMNH DOT 10720* & Central African Republic \\
\hline & FMNH $200858^{+}$ & Uganda \\
\hline & FMNH $200861^{\dagger}$ & Uganda \\
\hline & FMNH $200862^{+}$ & Uganda \\
\hline & FMNH $200865^{\dagger}$ & Uganda \\
\hline & FMNH 200867 & Uganda \\
\hline & FMNH 200858 & Uganda \\
\hline & FMNH 273185 & Cameroon \\
\hline & FMNH 273192 & Cameroon \\
\hline & FMNH $304693^{+}$ & Zaire \\
\hline L. funebris & AMNH DOT 7108* & Kenya \\
\hline
\end{tabular}

a Samples are from the American Museum of Natural History (AMNH) and the Field Museum of Natural History (FMNH).

${ }^{\mathrm{b}}$ Specimens used only in phylogenetic analyses are indicated by an asterisk; specimens used only in morphometric analysis are indicated by a dagger.

Italicized specimen numbers represent $L$. p. holomelas individuals recorded as having gray irides. 